\title{
Screening pre-diabetes and obese women in an early stage of renal dysfucntion from serum 25- hydroxy vitamin D and serum parathormone levels with age, body mass index and fast plasma glucose
}

\author{
Ernest Emilion ${ }^{1}$ and Richard Emilion ${ }^{2}$ \\ ${ }^{1}$ Medicine Doctor at Community Clinic, Paris, France \\ ${ }^{2}$ MAPMO Laboratory, Orleans University, B.P. 6759, 45067 Orleans cedex 2, France
}

\begin{abstract}
It is known that vitamin D may affect renal homeostasis and is inversely correlated with serum parathormone (PTH). We proposed some classes of levels of serum 25- hydroxyvitamin D (25(OH)D) and PTH, we wondered whether fast plasma glucose concentrations or less costly criterion as Age or BMI could be used to predict classification of each woman of our cohort in classes of serum $25(\mathrm{OH}) \mathrm{D} / \mathrm{PTH}$ concentrations. Measurements of serum $25(\mathrm{OH}) \mathrm{D}$ and serum $\mathrm{PTH}$ were done, among 165 adult African migrants women. ROC analysis was used to identify serum $25(\mathrm{OH}) \mathrm{D}$ and serum PTH thresholds. Machine-learning tools were performed to predict classes of $25(\mathrm{OH}) \mathrm{D}$ and serum PTH levels from age, body mass index and fast plasma glucose. A threshold of serum $25(\mathrm{OH}) \mathrm{D}$ of $50 \pm 5 \mathrm{nmol} / \mathrm{L}$ and serum PTH of $44 \pm 6 \mathrm{ng} / \mathrm{L}$ level was found with a sensitivity of $86 \%$, a specificity of $83 \%$. We identified $40 \%$ of the sample as forties women, obese and pre-diabetic in an early stage of kidney disorders. Estimation with Fast Capillary Glucose measurement instead of Fast Plasma Glucose could be a less costly method to screen glucose and vitamin $\mathrm{D}$ status among migrant women.
\end{abstract}

\section{Introduction}

Vitamin D is required for efficient absorption of dietary calcium and for good health. It is obtained from sun exposure and diet and is converted in the liver to hydroxycholecalciferol $(25(\mathrm{OH}) \mathrm{D})$, the primary storage form of the vitamin. Subsequently $25(\mathrm{OH})$ $\mathrm{D}$ is converted in the kidney into its biologically active form, 1,25 dihydroxyvitamin $\mathrm{D}\left(1,25(\mathrm{OH})_{2} \mathrm{D}\right)$. When serum calcium declines, parathyroid hormone (PTH) increases, which results in osteoclast activity and release of calcium from bone. PTH also acts on the kidney to stimulates the conversion of $25(\mathrm{OH}) \mathrm{D}$ to $1,25(\mathrm{OH})_{2} \mathrm{D}$. In turn, $1,25(\mathrm{OH})_{2} \mathrm{D}$ increases intestinal calcium absorption. Reduction in $25(\mathrm{OH}) \mathrm{D}$ levels is associated with impaired calcium absorption and a compensatory increase in the level of PTH which, in turn, stimulates bone resorption [1]. Usually, vitamin D status is defined according to serum $25(\mathrm{OH}) \mathrm{D}$ concentration $[2,3]$. There is a significant inverse relationship between circulating $25(\mathrm{OH}) \mathrm{D}$ and serum PTH. When $25(\mathrm{OH}) \mathrm{D}$ availability declines, serum $1,25(\mathrm{OH})_{2} \mathrm{D}$ declines, and this results in reduced calcium absorption, a transient decline in serum calcium concentration, and stimulation of PTH secretion known as secondary hyperparathyroidism, conventionally defined as a PTH level $>65 \mathrm{ng} / \mathrm{L}$ [4]. Although, there is no universal consensus as to the optimum threshold limit of serum $25(\mathrm{OH}) \mathrm{D}$ the most commonly used way to assess that serum $25(\mathrm{OH}) \mathrm{D}$ cut-off is based on the negative relationship between serum $25(\mathrm{OH}) \mathrm{D}$ and PTH levels and it is proposed that it is the serum concentration of $25(\mathrm{OH}) \mathrm{D}$ at which PTH levels are minimized [5]. Then, in many studies non parametric methods as regression models were used to estimations reliable serum 25(OH)D cut-offs. However this method often implied to exclude a huge part of the sample [5-7]. Vitamin D status is defined by serum $25(\mathrm{OH}) \mathrm{D}$ con- centration $[1,2]$, which is influenced in turn by various factors including latitude, skin pigmentation, dietary and calcium intake [3]. Recently effects of vitamin D on renal function were reported, emerging evidence suggests that the progression of renal disorders and many of the cardiovascular complications may be linked to low vitamin D status [8]. African population is especially concern as a population with strong prevalence of low vitamin D status [9]. Our purpose was to determine classes of serum $25(\mathrm{OH}) \mathrm{D} / \mathrm{PTH}$ levels with use of 25(OH)D threshold below which PTH concentrations increases. Then, in our sample, we wondered whether FPG measurement or less costly criterion as Age or BMI could be used for each African migrant women for the prediction of her class of serum 25(OH)D/PTH levels.

\section{Methods}

\section{Patients}

The study was conducted in a Community Clinic lo- cated in eastern Paris at latitude $48.5 \mathrm{~N}$. The inclusion criteria specified adult African migrant women. Patients were excluded if younger than 18 years old,

Correspondence to: Ernest Emilion, Medicine Doctor at Community Clinic, Paris, 116 rue de Belleville, 75020 Paris, France, Tel: (33) 07837000 40;E-mail: eemilion@gmail.com

Key words: 25-hydroxyvitamin D, parathormone, fast glucose plasma, body mass index data mining

Received: June 12, 2015; Accepted: July 09, 2015; Published: July 12, 2015 
Emilion E (2015) Screening pre-diabetes and obese women in an early stage of renal dysfucntion from serum 25- hydroxy vitamin D and serum parathormone levels with age, body mass index and fast plasma glucose

had a body mass index (BMI) $>30$, or if their medical history might influence their serum PTH concentration (hyper- or hypocalcemia, renal insufficiency, medical treatment: bisphosphonates, anticonvulsants, lithium). In France, a migrant is defined as someone who was born in a foreign country as a non-French citizen. One hundred sixty-five migrant adult women with a mean age of $38.6 \pm 9.9$ years were included in the study between February 2008 and November 2009. This study was approved by the Independent Ethics Committee of Paris IV and all participants provided written informed consent.

\section{Calcium intake}

We used a food-frequency type self-assessment questionnary to estimate the daily calcium intake of each patient [10].

\section{Measurements}

Serum 25(OH)D was measured using chemiluminescence methodology (Diasorin, LIAISON ${ }^{\star}$ ) [11] by the Pasteur Cerba laboratory. The test interval measure was between 10 and $350 \mathrm{nmol} / \mathrm{L}$. Over all seasons of the year and for both genders, 25(OH)D norms [12] were as follows: Recommended levels: $75-200 \mathrm{nmol} / \mathrm{L}(30-80 \mu \mathrm{g} / \mathrm{L})$, Insufficiency: $25-75 \mathrm{nmol} / \mathrm{L}(10-30 \mu \mathrm{g} / \mathrm{L})$, Deficiency: $<25 \mathrm{nmol} / \mathrm{L}(<10$ $\mu \mathrm{g} / \mathrm{L})$. Functional sensitivity was $17.5 \mathrm{nmol} / \mathrm{L}$ with interassay coefficients of variation (CVs) of $12.9 \%$. PTH was measured by chemiluminescence using a LIAISON ${ }^{\circledR} \mathrm{N}$-tactTM PTH test. The test interval measure was be- tween 1 and $2,000 \mathrm{~cm} / \mathrm{L}$ and normal PTH levels were $<51 \mathrm{~cm} / \mathrm{L}$ [13]. Samples were collected in dry tubes for serum $25(\mathrm{OH}) \mathrm{D}$, in tubes with EDTA for PTH. FPG was measured with hexokinase technic -Cobas c501 norms were 4.11-5.89 mmol/L. Hbalc were measured with high pressure chromatography-D10 Biorad norms were $<6$. Serum Phosphorus was measured with phosphomolybdate technicCobas c501 norms were $27-45 \mathrm{mg} / \mathrm{L}$. Serum alkaline phosphatases were measured with IFCC colometric technic-Cobas c501 norms were 40-130 U/L. Renal function was estimated by clearance creatinine, calculated using the Cockcroft and Gault equation and serum creatinine. After an overnight fast, blood samples were drawn from 8.00 to 10.00 a.m. for measurement of $25(\mathrm{OH}) \mathrm{D}, \mathrm{PTH}$, and calcium. Urines creatinin was measured with Jaffe technic-Cobas c501 norms were 7-14 mmol/ day. Urines phosphorus was measured with phosphomolybdate-Cobas c501 norms were 13-42 mmol/day. Renal tubular phosphate handling was assessed for each patient as the ratio of the maximum rate of tubular phosphate reabsorption (TmP) to the glomerular filtration rate (GFR) as $\mathrm{TmP} / \mathrm{GFR}=$ serum phosphate -(urines phosphate $\mathrm{x}$ serum creatinin/ urines creatinin), norms were $2,8-4,4 \mathrm{mg} / \mathrm{dL}$ [14].

\section{Statistical analysis}

Gaussian mixture model: The Expectation-Maximization (EM) algorithm [15] was used to estimate FPG distributions as a Gaussian mixture.

Regression analysis: We used non-parametric kernel regression method implemented in the 'npreg' function of the Hayfield et al. (np) package [16] for the R software version 2.10.0.

ROC analysis: The diagnostic performance of a test, or the accuracy of a test to discriminate diseased cases from normal cases is evaluated using ROC curve analysis $[17,18]$. In practice the AUC performs very well and is often used when a general measure of predictiveness is desired [19]. In this study, we tested all serum $25(\mathrm{OH}) \mathrm{D}$ values in the range of class 1 levels, $38-60 \mathrm{nmol} / \mathrm{L}$, previously estimated with Gaussian mixture model fitted for serum 25(OH)D distributions. We noted ( $\mathrm{x}$ ) as a variable value. We choose PTH values in the Gaussian mixture ranges. Each point on the ROC curve represents a sensitivity/ specificity pair corresponding to a particular decision threshold. We took the best threshold point [20].

Machine learning: We used Adaboost [21,22] to estimated classes of $25(\mathrm{OH}) \mathrm{D} / \mathrm{PTH}$. Boosting is an approach to machine learning based on the idea of creating a highly accurate prediction rule by combining many relatively weak and inaccurate rules. Adaboost algorithm is particular because it needs no prior knowledge of the accuracies of the weak hypotheses. It adapts to these accuracies and generates a weighted majority hypothesis in which the weight of each weak hypothesis is a function of its accuracy. Based on 20 repetitions of 10 -fold cross validation $(\mathrm{CV})$, Adaboost algorithm was used to predict from data observed classification of patients in different classes of serum $25(\mathrm{OH})$ $\mathrm{D}$ levels and serum PTH levels defined with our 25(OH)D/PTH threshold as below. We choose three strong predictor variables selected as FPG, BMI and age. We used Adaboost algorithm implemented in R software version 2.10.0.

\section{Results}

\section{Basic statistics}

Shown in Table 1.

\section{ROC analysis}

In the whole sample, ROC analysis found a decision threshold point of serum $25(\mathrm{OH}) \mathrm{D}$ of $65 \mathrm{nmol} / \mathrm{L}$ and PTH of $44 \mathrm{ng} / \mathrm{L}$ with a sensitivity of $86 \%$, a specificity of $81 \%$, a positive predictive value of $96 \%$ and a negative predictive value of $57 \%$. When laboratory norms were used the best point of decision was of a sensitivity of $58 \%$, a positive predictive value of $100 \%$, a negative predictive value of $0 \%$ and a specificity was not calculable.

\section{Classes of 25(OH)D/PTH levels (Tables 2 and 3).}

We found four classes of serum $25(\mathrm{OH}) \mathrm{D}$ and serum PTH concentrations. We noticed that there was two classes of levels with a weak relationship between serum $25(\mathrm{OH}) \mathrm{D}$ and serum $\mathrm{PTH}$ as class 4 (serum 25(OH)D $>65 \mathrm{nmol} / \mathrm{L}$, serum PTH $\geq 44 \mathrm{ng} / \mathrm{L}$ ) and class 2 (serum $25(\mathrm{OH}) \mathrm{D} \leq 65 \mathrm{nmol} / \mathrm{L}$, serum $\mathrm{PTH}<44 \mathrm{ng} / \mathrm{L}$ ). And two classes of levels with a strong relationship between serum $25(\mathrm{OH}) \mathrm{D}$ and serum PTH concentrations as class 1 (serum $25(\mathrm{OH}) \mathrm{D} \leq 65 \mathrm{nmol} / \mathrm{L}$, serum $\mathrm{PTH} \geq 44 \mathrm{ng} / \mathrm{L}$ ) and class 3 (serum $25(\mathrm{OH}) \mathrm{D}>65 \mathrm{nmol} / \mathrm{L}$, serum PTH $<44 \mathrm{ng} / \mathrm{L}$ ). FPG distributions.

\section{Clearance creatinin distributions}

The EM algorithm provided the estimates of four Gaussian bell curves: subclass $\mathrm{R}$ (mean $1=97.224 \pm 1.829$, component weight: $1 \%)$, subclass $\mathrm{E}(\mathrm{mean}=111.375 \pm 5.743$, component weight: $48.5 \%)$, subclass I (mean=117.224 \pm 1.829 , component weight: $33.2 \%)$, subclass $\mathrm{N}($ mean $=75.733 \pm 8.636$, component weight: $8 \%)$.

Table 1. Basic statistics.

\begin{tabular}{|l|c|}
\hline African migrants women & $(\mathbf{n = 1 6 5})$ \\
\hline Mean age & $38.6 \pm 9.9$ \\
\hline Clearance creatinine (ml/min) & $119.32 \pm 36$ \\
\hline Daily Calcium Intakes (mg/day) & $800.59 \pm 303.16$ \\
\hline Baseline calcium intakes & $50 \%$ \\
\hline Milk products & $14 \%$ \\
\hline Mineral waters & $36 \%$ \\
\hline Others & \\
\hline
\end{tabular}


Emilion E (2015) Screening pre-diabetes and obese women in an early stage of renal dysfucntion from serum 25- hydroxy vitamin D and serum parathormone levels with age, body mass index and fast plasma glucose

Table 2. Means of 25(OH)D/PTH level classes.

\begin{tabular}{|c|c|c|c|c|}
\hline$n=165$ & $\begin{array}{c}\text { Class } 1(40 \%) \\
n_{1}=66\end{array}$ & $\begin{array}{c}\text { Class } 2(32 \%) \\
n_{2}=52\end{array}$ & $\begin{array}{c}\text { Class } 3(15 \%) \\
n_{3}=25\end{array}$ & $\begin{array}{c}\text { Class } 4(13 \%) \\
n_{4}=22\end{array}$ \\
\hline Calcium intakes (mg/d) & $635.42 \pm 24.13$ & $482.5 \pm 28.99$ & $1137.47 \pm 31.34$ & $1783.28 \pm 31.16$ \\
\hline Age (years) & $43 \pm 15$ & $37 \pm 6$ & $26 \pm 7$ & $57 \pm 16$ \\
\hline BMI $\left(\mathrm{kg} / \mathrm{m}^{2}\right)$ & $26.48 \pm 7.54$ & $21.5 \pm 5.4$ & $23.71 \pm 0.66$ & $33.45 \pm 6.33$ \\
\hline FGP (mg/dL) & $530 \pm 89$ & $467 \pm 44$ & $494 \pm 11$ & $542 \pm 61$ \\
\hline HBA1C & $5.75 \pm 0.66$ & $5.66 \pm 0.31$ & $6.20 \pm 0.95$ & $7.07 \pm 2.19$ \\
\hline Serum Creatinin $(\mathrm{mg} / \mathrm{L})$ & $11.61 \pm 1.54$ & $7.52 \pm 1.35$ & $6.7 \pm 0.82$ & $9.62 \pm 2.51$ \\
\hline Clearance Creatinin $(\mathrm{ml} / \mathrm{mn})$ & $60.31 \pm 13.70$ & $81.25 \pm 26.87$ & $92.53 \pm 30.24$ & $70.72 \pm 14.59$ \\
\hline Serum Phosphore (mg/L) & $29.2 \pm 2.2$ & $34.6 \pm 2.4$ & $38.4 \pm 1.7$ & $32.3 \pm 2.8$ \\
\hline Serum Alkalin Phosphatases & $95 \pm 16.26$ & $58.7 \pm 12.14$ & $62 \pm 24.11$ & $75 \pm 5.76$ \\
\hline Serum PTH (ng/L) & $77.53 \pm 14.21$ & $32.42 \pm 4.40$ & $21.98 \pm 4.02$ & $60.18 \pm 3.43$ \\
\hline Serum 25(OH)D (nmol/L) & $31.38 \pm 14.71$ & $41.62 \pm 8.32$ & $80 \pm 7.07$ & $88.02 \pm 21.78$ \\
\hline Urine Creatinin (mmol/d) & $16.17 \pm 3.71$ & $11.98 \pm 5.81$ & $7.51 \pm 3.10$ & $17.57 \pm 10.22$ \\
\hline Urine Phosphore (mmol/d) & $26.24 \pm 9.92$ & $11.35 \pm 0.63$ & $3.24 \pm 0.83$ & $15.43 \pm 2.37$ \\
\hline TmP/GFR (mg/dl) & $2.80 \pm 0.53$ & $3.17 \pm 0.57$ & $3.49 \pm 0.32$ & $3.17 \pm 0.40$ \\
\hline
\end{tabular}

Table 3. Comparing class means: Wilcoxon tests with significant p-values.

\begin{tabular}{|c|c|c|c|c|c|c|}
\hline & Class1 vs. Class2 & Class 1 vs. Class 3 & Class1 vs. Class 4 & Class 2 vs. Class 3 & Class 2 vs. Class 4 & Class 3 vs. Class 4 \\
\hline Calcium intakes (mg/d) & $\mathrm{m}_{1}>\mathrm{m}_{2}(<0.01)$ & $\mathrm{m}_{1}<\mathrm{m}_{3}(<0.01)$ & $\mathrm{m}_{1}<\mathrm{m}_{4}(<0.01)$ & $\mathrm{m}_{2}<\mathrm{m}_{3}(<0.01)$ & $\mathrm{m}_{2}<\mathrm{m}_{4}(<0.01)$ & $\mathrm{m}_{3}<\mathrm{m}_{4}(<0.01)$ \\
\hline Age (years) & $\mathrm{m}_{1}>\mathrm{m}_{2}(0.03)$ & $\mathrm{m}_{1}>\mathrm{m}_{3}(<0.01)$ & $\mathrm{m}_{1}<\mathrm{m}_{4}(<0.01)$ & $\mathrm{m}_{2}<\mathrm{m}_{3}(<0.01)$ & $\mathrm{m}_{2}<\mathrm{m}_{4}(<0.01)$ & $\mathrm{m}_{3}<\mathrm{m}_{4}(<0.01)$ \\
\hline BMI $\left(\mathrm{kg} / \mathrm{m}^{2}\right)$ & $\mathrm{m}_{1}>\mathrm{m}_{2}(<0.01)$ & $\mathrm{m}_{1}>\mathrm{m}_{3}(0.01)$ & $\mathrm{m}_{1}>\mathrm{m}_{4}(<0.02)$ & $\mathrm{m}_{2}>\mathrm{m}_{3}(0.06)$ & $\mathrm{m}_{2}<\mathrm{m}_{4}(0.03)$ & $\mathrm{m}_{3}<\mathrm{m}_{4}(<0.01)$ \\
\hline FPG (mg/dL) & $\mathrm{m}_{1}>\mathrm{m}_{2}(<0.01)$ & $\mathrm{m}_{1}>\mathrm{m}_{3}(<0.01)$ & $\mathrm{m}_{1}<\mathrm{m}_{4}(0.08)$ & $\mathrm{m}_{2}<\mathrm{m}_{3}(<0.01)$ & $\mathrm{m}_{2}<\mathrm{m}_{4}(0.01)$ & $\mathrm{m}_{3}<\mathrm{m}_{4}(0.08)$ \\
\hline HbA1C (\%) & $\mathrm{m}_{1}>\mathrm{m}_{2}(0.79)$ & $\mathrm{m}_{1}<\mathrm{m}_{3}(0.07)$ & $\mathrm{m}_{1}<\mathrm{m}_{4}(0.06)$ & $\mathrm{m}_{2}<\mathrm{m}_{3}(0.04)$ & $\mathrm{m}_{2}<\mathrm{m}_{4}(0.04)$ & $\mathrm{m}_{3}<\mathrm{m}_{4}(<0.01)$ \\
\hline Serum Creatinin & $\mathrm{m}_{1}>\mathrm{m}_{2}(<0.01)$ & $\mathrm{m}_{1}<\mathrm{m}_{3}(0.20)$ & $\mathrm{m}_{1}<\mathrm{m}_{4}(0.11)$ & $\mathrm{m}_{2}<\mathrm{m}_{3}(0.30)$ & $\mathrm{m}_{2}<\mathrm{m}_{4}(0.22)$ & $\mathrm{m}_{3}<\mathrm{m}_{4}(<0.01)$ \\
\hline Clearence Creatinin & $\mathrm{m}_{1}<\mathrm{m}_{2}(0.10)$ & $\mathrm{m}_{1}>\mathrm{m}_{3}(0.28)$ & $\mathrm{m}_{1}>\mathrm{m}_{4}(0.01)$ & $\mathrm{m}_{2}>\mathrm{m}_{3}(<0.01)$ & $\mathrm{m}_{2}>\mathrm{m}_{4}(<0.01)$ & $\mathrm{m}_{3}<\mathrm{m}_{4}(0.53)$ \\
\hline Serum phosphore & $\mathrm{m}_{1}<\mathrm{m}_{2}(0.30)$ & $\mathrm{m}_{1}<\mathrm{m}_{3}(0.07)$ & $\mathrm{m}_{1}<\mathrm{m}_{4}(0.23)$ & $\mathrm{m}_{2}<\mathrm{m}_{3}(0.15)$ & $\mathrm{m}_{2}<\mathrm{m}_{4}(0.69)$ & $\mathrm{m}_{3}>\mathrm{m}_{4}(0.50)$ \\
\hline Serum alkalins phosphates & $\mathrm{m}_{1}>\mathrm{m}_{2}(<0.01)$ & $\mathrm{m}_{1}>\mathrm{m}_{3}(<0.01)$ & $\mathrm{m}_{1}<\mathrm{m}_{4}(<0.01)$ & $\mathrm{m}_{2}<\mathrm{m}_{3}(0.09)$ & $\mathrm{m}_{2}<\mathrm{m}_{4}(0.03)$ & $\mathrm{m}_{3}<\mathrm{m}_{4}(0.02)$ \\
\hline Serum PTH (ng/L) & $\mathrm{m}_{1}<\mathrm{m}_{2}(<0.01)$ & $\mathrm{m}_{1}<\mathrm{m}_{3}(<0.01)$ & $\mathrm{m}_{1}>\mathrm{m}_{4}(<0.01)$ & $\mathrm{m}_{2}<\mathrm{m}_{3}(0.03)$ & $\mathrm{m}_{2}<\mathrm{m}_{4}(<0.01)$ & $\mathrm{m}_{3}<\mathrm{m}_{4}(<0.01)$ \\
\hline Serum 25(OH)D (nmol/L) & $\mathrm{m}_{1}<\mathrm{m}_{2}(<0.01)$ & $\mathrm{m}_{1}<\mathrm{m}_{3}(<0.01)$ & $\mathrm{m}_{1}<\mathrm{m}_{4}(<0.01)$ & $\mathrm{m}_{2}<\mathrm{m}_{3}(<0.01)$ & $\mathrm{m}_{2}<\mathrm{m}_{4}(<0.01)$ & $\mathrm{m}_{3}<\mathrm{m}_{4}(<0.01)$ \\
\hline Urinary Creatinin & $\mathrm{m}_{1}<\mathrm{m}_{2}(0.75)$ & $\mathrm{m}_{1}>\mathrm{m}_{3}(0.08)$ & $\mathrm{m}_{1}>\mathrm{m}_{4}(<0.01)$ & $\mathrm{m}_{2}<\mathrm{m}_{3}(<0.01)$ & $\mathrm{m}_{2}<\mathrm{m}_{4}(<0.01)$ & $\mathrm{m}_{3}<\mathrm{m}_{4}(0.06)$ \\
\hline Urinary Phosphore & $\mathrm{m}_{1}<\mathrm{m}_{2}(<0.01)$ & $\mathrm{m}_{1}>\mathrm{m}_{3}(<0.01)$ & $\mathrm{m}_{1}<\mathrm{m}_{4}(0.03)$ & $\mathrm{m}_{2}>\mathrm{m}_{3}(<0.01)$ & $\mathrm{m}_{2}<\mathrm{m}_{4}(<0.01)$ & $\mathrm{m}_{3}<\mathrm{m}_{4}(<0.01)$ \\
\hline TmP/GFR (mg/dl) & $\mathrm{m}_{1}<\mathrm{m}_{2}(0.07)$ & $\mathrm{m}_{1}<\mathrm{m}_{3}(<0.01)$ & $\mathrm{m}_{1}<\mathrm{m}_{4}(0.03)$ & $\mathrm{m}_{2}<\mathrm{m}_{3}(0.06)$ & $\mathrm{m}_{2}>\mathrm{m}_{4}(0.08)$ & $\mathrm{m}_{3}>\mathrm{m}_{4}(0.04)$ \\
\hline
\end{tabular}

Table 4. Performance of Adaboost algorithm for 25(OH)D/PTH classes data based on 20 Repetitions of 10-fold CV (S.D. in parentheses).

\begin{tabular}{|c|c|c|c|}
\hline Accuracy & Sensitivity & Specificity & Positive Predictive value \\
\hline $.998(.002)$ & $1.00(.002)$ & $.994(.003)$ & $.993(.001)$ \\
\hline
\end{tabular}

\section{Adaboost algorithm}

We found age, BMI and FPG as stronger criterions to discriminate each patient of our sample. Classes of $25(\mathrm{OH}) \mathrm{D} / \mathrm{PTH}$ levels were predicted with an error rate of less than $1 \%$ (Table 4$)$.

\section{Discussion}

We chose to examine this population as it was characterized by low dermal synthesis of vitamin D due to high melanin pigmentation [23], low 25(OH)D levels, and reactive increases in $\mathrm{PTH}$, which are highly prevalent in African migrants living in Northern latitudes [24]. Furthermore recent studies have shown that elevated PTH levels are associated with increased cardiovascular risk in the general population $[25,26]$ and it is known that high PTH concentrations lead to a decreased of the kidney function [27]. New evidence has now established that the role of vitamin $\mathrm{D}$ is no longer solely restricted to its classical function of maintaining calcium and phosphate homeostasis, Vitamin D appears to play a more extensive role in a variety of tissues including the renal, cardiovascular systems [8]. Thus, identifying a 25(OH)D threshold below which PTH concentrations are elevated might be of use in estimating cardiovascular or renal disorders risk due to high PTH concentrations.

\section{Calcium sufficiency}

In our study, the daily calcium intake of African women, estimated with $20 \%$ precision [10], was higher than $400 \mathrm{mg} /$ day. This estimate was higher than the $300 \mathrm{mg} /$ day reported by Prentice et al. among African women living in Africa [28-31], and close to the $900 \mathrm{mg} / \mathrm{day}$ recommended for French women younger than 55 years old [32]. However, Heaney et al. estimated that African American women require $300 \mathrm{mg}$ less calcium per day compared to white women [33], which suggests that the average calcium daily intake of African women in our sample was sufficient.

\section{Serum $25(\mathrm{OH})$ D and Serum PTH cut-offs}

In the litterature, the serum $25(\mathrm{OH}) \mathrm{D}$ threshold corresponding with the PTH inflection point has been interpreted as indicative of optimal calcium homeostasis and proposed to defining recommended vitamin D intake [5,34]. According to Steingrimsdottir et al., one limit 
to this approach is because there is considerable variation in the level of 25(OH)D associated with any given serum PTH concentration, and reported threshold levels have varied greatly from 8 to $44 \mathrm{ng} / \mathrm{L}$ [35]. In our study, serum PTH cut-offs found were in similar PTH thresholds levels reported. According to Sahota et al., as low 25(OH)D status is defined biochemically as the degree of low serum $25(\mathrm{OH}) \mathrm{D}$ resulting in an increase of PTH levels, it may be more appropriate to include a threshold level of PTH in the disease definition [36]. In our study we found PTH cut-offs within conventional normal range. According to Sahota et al. [36], it is evident that in the presence of low $25(\mathrm{OH})$ $\mathrm{D}$ status, the threshold defining secondary hyperparathyroidism is probably in the upper tertile of the laboratory reference range and that defining 'functional low PTH levels' in the lower tertile. It was similar to ours results. In our study, ROC analysis highlighted some interesting values. We noticed that values $25(\mathrm{OH}) / \mathrm{PTH}$ cut-offs found were respectively similar to value of mean $25(\mathrm{OH}) \mathrm{D}$ classes $1-2$ and to value of mean PTH classes A-B estimated with our Gaussians mixtures model [7]. Our previous 25(OH)D/PTH curve showed serum $25(\mathrm{OH})$ $\mathrm{D}$ thresholds corresponding to points of inflection of PTH levels similar to $25(\mathrm{OH}) \mathrm{D} / \mathrm{PTH}$ cut-offs estimated with ROC analysis.

Most authors used regression models to estimate serum 25(OH) $\mathrm{D}$ thresholds and to get more accuracy it need frequently to exclude as outliers a significant part of patients, an average of $40 \%$ of the sample [5-7]. In our previous study, we had to remove $30 \%$ of the sample to increase estimations accuracy with Kernel regression model otherwise it was not reliable. In this study, the $25(\mathrm{OH}) / \mathrm{PTH}$ test was valuable when $4 \%$ of the sample was removed. This suggests that ROC analysis could be equally applicable as regression models. Moreover, ROC graphs are commonly used in medical decision-making and in recent years have been used increasingly in machine learning and data mining research [37]. With robust non parametric ROC analysis we estimated significant serum $25(\mathrm{OH}) \mathrm{D} / \mathrm{PTH}$ thresholds points without removed any outliers or very few. This appears to be the major difference compared with our previous Kernel regression model method.

\section{Classes of behaviors}

It is well-known that sunlight it's the principal source of vitamin $\mathrm{D}$ and its increases serum $25(\mathrm{OH}) \mathrm{D}$ concentrations through the skin. In our study we found classes 3 and 4 of women with high serum $25(\mathrm{OH}) \mathrm{D}$ levels suggesting they had more daylights exposition than classes 1 and 2 of women with low serum $25(\mathrm{OH}) \mathrm{D}$ levels. There is no effect of age on $25(\mathrm{OH})$ D concentrations while in human serum PTH concentrations increases with aging [38]. It could partly explain high serum PTH levels in the oldest classes of women and low serum PTH levels in the youngest classes of women.

\section{Classes of renal status}

We noticed that estimations of means of our quadruple Gaussian of creatinin clearance distributions were similar ranges of those of classification of chronic kidney diseases (CCKD) [39]. As we did not estimate the similar lower ranges of CCKD stage 5 , it was agree that no women with end stage renal disease were selected in our sample. According to Falch et al. there a relation between age and serum phosphate levels in adults, serum phosphate levels decline with age, except for a transient increase during the peri-menopausal period in women [40]. Cirillo et al. have shown that the decrease in the TmP:GFR ratio with age was similar to that in serum phosphate levels, the ageassociated decline in serum phosphate levels was not associated with hypocalcemia and hypocalciuria, nor with indexes of protein and salt intake [41]. The authors reported that the increase in serum phosphate levels in women between the ages of 45 and 54 years was probably not related to age itself, but rather to menstrual status. In our study forties women in class 1 had a not normal decreased TmP:GFR ratio and that could suggested possible renal tubular defects . According to Malluche et al. in the early stages of renal failure, hyperparathyroidism develops as a compensatory mechanism to control serum levels of phosphorus [42]. As kidney dysfunction progresses this ability to maintain mineral homeostasis is lost leading to the development of renal diseases. Then at least, women of our class 1 could be suspected to be in an early stage of kidney dysfunction. Leibovitch et al. reported that serum alkaline phosphatase maybe a marker for involvement of the kidneys in pathological processes and increased serum alkaline phosphatase is a possible indicator of renal damage [43]. In our sample, among classes of low serum 25(OH)D concentrations, class 1 of forties women had significant highest serum alkaline phosphatase levels. In our study, when we took in account BMI [44] and definition of glucose disorders based on HbAlc classification [45] we determined class of low serum $25(\mathrm{OH}) \mathrm{D}$ concentrations and high serum TSH levels, as class 1 of oldest forties women, obese and pre-diabetic in an early stage of kidney disorders. Class of high serum 25(OH)D levels and low serum PTH concentrations determined as class 4 of fifties overweight and diabetic women. We classified younger forties and thirties subjects as classes of slender women with low serum PTH concentrations and with a high risk for developing glucose disorders in the future.

Discriminant factors of classes of levels and machine learning. In our study we used three criterions that classified whole sample, as FPG, BMI and age. From women FPG measurement and using boosting data method as Adaboost we estimated classes of serum 25(OH)D and serum PTH levels. Each patient was classified precisely in a one of the four classes of 25(OH)/D levels defined.

\section{Limitations}

We noticed that diagnostic of chronic renal diseases need confirmation with at least two different and closely following control of the renal function. In this study we did not practice second blood and urinary analysis of renal function. Our results could be understand as focus on renal function should be a health priority in medical monitoring program among African migrant women. Note that there are non-calcemic effects of vitamin D in other biological metabolisms which likely need higher $25(\mathrm{OH}) \mathrm{D}$ concentrations than those required to maintain PTH secretion [46]. Therefore, 25(OH)D threshold of $65 \mathrm{nmol} / \mathrm{L}$ should not be interpreted as optimum vitamin D status. Although the importance of preventing undue increases in serum PTH for bone health is generally recognized, evidence is lacking for identifying the exact levels that may be detrimental [47]. Then, serum PTH cut-off of $44 \mathrm{ng} / \mathrm{L}$ should not be interpreted as absolute PTH cut-off.

\section{Conclusion}

From our sample of 165 calcium-sufficient African migrant women living in Paris, ROC analysis found a 25(OH)D threshold of $65 \mathrm{nmol} / \mathrm{L}$ and PTH of $44 \mathrm{ng} / \mathrm{L}$ in the whole sample. We identified $40 \%$ of the sample as forties women, obese and pre-diabetic in an early stage of kidney disorders. With our model of machine learning From Age, Body Mass Index and Fast Plasma Glucose we classified each patient of our sample in different classes of 25 hydroxyvitamin D and serum parathormone levels with a sensitivity of $99 \%$, a specificity of $99 \%$, a true positive value of $98 \%$ and a true negative value of $98 \%$. Estimation with Fast Capillary Glucose measurement instead of Fast Plasma Glucose could be a less costly method to screen glucose and vitamin 
Emilion E (2015) Screening pre-diabetes and obese women in an early stage of renal dysfucntion from serum 25- hydroxy vitamin D and serum parathormone levels with age, body mass index and fast plasma glucose

D status among African migrants women. Estimating vitamin status and glucose status in others samples of population might be of interest.

\section{References}

1. DeLuca HF (2004) Overview of general physiologic features and functions of vitamin D. Am J Clin Nutr 80: 1689S-96S. [Crossref]

2. Bandeira F, Griz L, Dreyer P, Eufrazino C, Bandeira C, et al. (2006) Vitamin D deficiency: A global perspective. Arq Bras Endocrinol Metabol 50: 640-646. [Crossref]

3. Webb AR, Pilbeam C, Hanafin N, Holick MF (1990) An evaluation of the relative contributions of exposure to sunlight and of diet to the circulating concentrations of 25-hydroxyvitamin D in an elderly nursing home population in Boston. Am J Clin Nutr 51: 1075-1081. [Crossref]

4. Holick MF (1990) The use and interpretation of assays for vitamin D and its metabolites. J Nutr 120 Suppl 11: 1464-1469. [Crossref]

5. Chapuy MC, Preziosi P, Maamer M, Arnaud S, Galan P, et al. (1997) Prevalence of vitamin D insufficiency in an adult normal population. Osteoporos Int 7: 439-443. [Crossref]

6. Aloia JF, Talwar SA, Pollack S, Feuerman M, Yeh JK (2006) Optimal vitamin D status and serum parathyroid hormone concentrations in African American women. Am J Clin Nutr 84: 602-609. [Crossref]

7. Emilion E, Emilion R (2011) Estimation of the $25(\mathrm{OH})$ vitamin D thresholds below which secondary hyperparathyroidism may occur among African migrant women in Paris. Int J Vitam Nutr Res 81: 218-224. [Crossref]

8. Williams S, Malatesta K, Norris K (2009) Vitamin D and chronic kidney disease. Ethn Dis 19: S5-8-11. [Crossref]

9. Cowie CC, Rust KF, Byrd-Holt DD, Eberhardt MS, Flegal KM, et al. (2006) Prevalence of diabetes and impaired fasting glucose in adults in the U.S. population: National Health And Nutrition Examination Survey 1999-2002. Diabetes Care 29: 1263-1268. [Crossref]

10. Fardellone P, Sebert JL, Bouraya M, Bonidan O, Leclercq G, et al. (1991) Evaluation of the calcium content of diet by frequential self-questionnaire. Rev Rhum Mal Osteoartic 58: 99-103. [Crossref]

11. Horst RL, Hollis BW (1999) Vitamin D assays and their clinical utility. In: Holick MF, (Edr.), Physiology, Molecular Bi- ology, and Clinical Applications, Humana Press Inc. Totowa, NJ: 239-227.

12. Holick MF (2006) High prevalence of vitamin D inadequacy and implications for health. Mayo Clin Proc 81: 353-373. [Crossref]

13. Souberbielle JC, Fayol V, Sault C, Lawson-Body E, Kahan A, et al. (2005) Assay-specific decision limits for two new automated parathyroid hormone and 25-hydroxyvitamin D assays. Clin Chem 51: 395-400. [Crossref]

14. Walton RJ, Bijvoet OL (1975) Nomogram for derivation of renal threshold phosphate concentration. Lancet 2: 309-310. [Crossref]

15. Dempster AP, Laird NM. and Rubin DB (1977) Maximum likelihood from incomplete data via the EM algorithm (with discussion). Journal of the Royal Statistical Society B39, 1-38.

16. Efron B (1979) Bootstrap Methods: Another Look at the Jackknife. The Annals of Statistics 7: 1-26.

17. Nadaraya EA (1965) On Nonparametric Estimates of Density Functions and regression curves. Theory Probab 10: 186-190.

18. Hand David J, Till Robert J (2001) A simple generalization of the area under the ROC curve for multiple class classification problems. Machine Learning 45: 171-186.

19. Provost F, Fawcett $\mathrm{T}$ (2001) Robust classification for imprecise environments. Machine Learning 44: 203-231.

20. Hanley JA, McNeil BJ (1982) The meaning and use of the area under a receiver operating characteristic (ROC) curve. Radiology 143: 29-36. [Crossref]

21. Moon H, Ahn H, Kodell RL, Baek S, Lin CJ, et al. (2007) Ensemble methods for classification of patients for personalized medicine with high-dimensional data. Artif Intell Med 41: 197-207. [Crossref]

22. Schapire RE (2013) Explaining Adaboost. Empirical Inference 2013: 37-52.

23. Aloia JF (2008) African Americans, 25-hydroxyvitamin D, and osteoporosis: a paradox. Am J Clin Nutr 88: 545S-550S. [Crossref]
24. Mithal A, Wahl DA, Bonjour JP, Burckhardt P, Dawson-Hughes B, et al. (2009) Global vitamin D status and determinants of hypovitaminosis D. Osteoporos Int 20: 1807 1820. [Crossref]

25. Pilz S, Tomaschitz A, Drechsler C, Ritz E, Boehm BO, et al. (2010) Parathyroid hormone level is associated with mortality and cardiovascular events in patients undergoing coronary angiography. Oxford Journals Medicine European Heart Journal, 31: 1591-1598. [Crossref]

26. Bhuriya MD, Li S, Chen SC, McCullough PA, Bakris GL (2009) Plasma Parathyroid Hormone Level and Prevalent Cardiovascular Disease in CKD Stages 3 and: An Analysis From the Kidney Early Evaluation Program (KEEP). American Jour- nal of Kidney Diseases 53: S3-S10. [Crossref]

27. Hörl WH (2004) The clinical consequences of secondary hyperparathyroidism: focus on clinical outcomes. Nephrol Dial Transplant 19 Suppl 5: V2-8. [Crossref]

28. Tillin T, Sattar N, Godsland IF, Hughes AD, Chaturvedi N, et al. (2014) Ethnicityspecific obesity cut-points in the development of type 2 diabetes a prospective study including three ethnic groups in the United Kingdom. Diabet Med 32: 226-234. [Crossref]

29. Barzilay JI, Spiekerman CF, Kuller LH, Burke GL, Bittner V, et al. (2001) Cardiovascular Health Study. Prevalence of clinical and isolated subclinical cardiovascular disease in older adults with glucose disorders: the Cardiovascular Health Study. Diabetes Care 24: 1233-1239. [Crossref]

30. Hyppönen E, Power C (2006) Vitamin D status and glucose homeostasis in the 1958 British birth cohort: the role of obesity. Diabetes Care 29: 2244-2246. [Crossref]

31. Yan L, Schoenmakers I, Zhou B, Jarjou LM, Smith E, et al. (2009) Ethnic differences in parathyroid hormone secretion and mineral metabolism in response to oral phosphate administration. Bone 45: 238-245. [Crossref]

32. Martin A (2001) Apports nutritionnels conseille's pour la population franc aise. In: AFSSA-CNERNA- CNRS. Tec et Doc Lavoisier, Paris.

33. Heaney RP (2002) The importance of calcium intake for lifelong skeletal health. Calcif Tissue Int 70: 70-73. [Crossref]

34. Dawson-Hughes B, Harris SS, Dallal GE (1997) Plasma calcidiol, season, and serum parathyroid hormone concentrations in healthy elderly men and women. Am J Clin Nutr 65: 67-71. [Crossref]

35. Steingrimsdottir L, Gunnarsson O, Indridason OS, Franzson L, Sigurdsson G (2005) Relationship between serum parathyroid hormone levels, vitamin D sufficiency, and calcium intake. JAMA 294: 2336-2341. [Crossref]

36. Sahota O, Mundey MK, San P, Godber IM, Lawson N, et al. (2004) The relationship between vitamin $\mathrm{D}$ and parathyroid hormone: calcium homeostasis, bone turnover, and bone mineral density in postmenopausal women with established osteoporosis. Bone 35: 312-319. [Crossref]

37. Tom Fawcett (2006) An introduction to ROC analysis. Pattern Recognition Letters 27: 861-874.

38. Vieth R, Ladak Y, Walfish PG (2003) Age-Related Changes in the 25-Hydroxyvitamin D Versus Parathyroid Hormone Relationship Suggest a Different Reason Why Older Adults Require More Vitamin D. J Clin Endocrinol Metab 88: 185-191. [Crossref]

39. Snyder S, Pendergraph B (2005) Detection and evaluation of chronic kidney disease Am Fam Physician 72: 1723-1732. [Crossref]

40. Falch JA, Gautvik KM (1988) A longitudinal study of pre- and postmenopausal changes in calcium metabolism. Bone 9: 15-19. [Crossref]

41. Cirillo M, Ciacci C, De Santo NG (2008) Age, renal tubular phosphate reabsorption, and serum phosphate levels in adults. N Engl J Med 359: 864-866. [Crossref]

42. Malluche HH, Mawad H, Monier-Faugere MC (2004) The importance of bone health in end-stage renal disease: out of the frying pan, into the fire? Nephrol Dial Transplant 19 Suppl 1: i9-13. [Crossref]

43. Leibovitch I, Ben-Chaim J, Ramon J, Goldwasser B (1991) Increased serum alkaline phosphatase activity: a possible indicator of renal damage. J Clin Lab Anal 5: 406-409. [Crossref]

44. Pinto-Sietsma SJ, Navis G, Janssen WM, de Zeeuw D, Gans RO, et al. (2003) A centra body fat distribution is related to renal function impairment, even in lean subjects. $\mathrm{Am}$ J Kidney Dis 41: 733-741. [Crossref]

45. American Diabetes Association (2010). Diagnosis and Classification of Diabetes Mellitus. Diabetes Care 33. 
Emilion E (2015) Screening pre-diabetes and obese women in an early stage of renal dysfucntion from serum 25- hydroxy vitamin D and serum parathormone levels with age, body mass index and fast plasma glucose

46. Grau MV, Baron JA, Sandler RS, Haile RW, Beach ML, et al. (2003) Vitamin D, calcium supplementation, and colorectal adenomas: results of a randomized trial. $J$ Natl Cancer Inst 95: 1765-1771. [Crossref]
47. Steingrimsdottir L, Gunnarsson O, Indridason OS, Franzson L, Sigurdsson G (2005) Relationship between serum parathyroid hormone levels, vitamin D sufficiency, and calcium intake. JAMA 294: 2336-2341. [Crossref]

Copyright: (C2015 Emilion E. This is an open-access article distributed under the terms of the Creative Commons Attribution License, which permits unrestricted use, distribution, and reproduction in any medium, provided the original author and source are credited. 